\title{
Powdered yoghurt produced by spray drying and freeze drying: a review
}

\author{
logurte em pó por atomização e liofilização: uma revisão
}

\author{
Geânderson dos Santos ${ }^{1 *}$, Regina Isabel Nogueira ${ }^{2}$, Amauri Rosenthal ${ }^{2}$ \\ 1'Instituto Federal de Educação, Ciência e Tecnologia de Sergipe, Campus Glória, Nossa Senhora da Glória/SE - Brasil \\ ${ }^{2}$ Embrapa Agroindústria de Alimentos, Guaratiba/RJ - Brasil
}

\section{*Corresponding Author}

Geânderson dos Santos, Instituto Federal de Educação, Ciência e Tecnologia de Sergipe, Campus Glória, Parque de Exposições João de Oliveira Dantas, Rodovia Juscelino Kubitschek, s/n, CEP: 49680-000, Nossa Senhora da Glória/SE - Brasil, email: geanderson.santos@ifs.edu.br

Cite as: Powdered yoghurt produced by spray drying and freeze drying: a review. Braz. J. Food Technol., v. 21, e2016127, 2018.

Received: Oct. 05, 2016; Accepted: Nov. 10, 2017

\section{Abstract}

Yoghurt is one of the dairy products most consumed worldwide but dehydrated yoghurt is still uncommon. Considered a nutritious food, yoghurt powder could be used as an ingredient or supplement in juices, cookies, ice cream and dairy beverages. Spray drying and freeze drying are the methods most widely used to dehydrate dairy products, and the process conditions are directly associated with the production costs and value of the final product. Due to osmotic and thermal stress during dehydration, it is often necessary to incorporate agents such as carriers, thermal protectants, cryo-protectants and stabilizers in order to improve the process yield, preserve nutrients and even facilitate rehydration of the product. Thus the present review presents the technologies available to obtain yoghurt powder, including the processes, drying agents, drying rates, rehydration conditions and survival of the lactic acid bacteria.

Keywords: Lactic acid bacteria; Conservation; Thermal protectants; Dehydration; Stability; Rehydration.

\section{Resumo}

O iogurte é um dos derivados lácteos mais consumidos no mundo. No entanto, o produto desidratado ainda é pouco comum. Alimento nutritivo, o iogurte em pó pode ser utilizado como ingrediente ou suplemento de sucos, biscoitos, sorvetes, doces e bebidas lácteas. O processo de secagem por spray driyng e a liofilização são os métodos mais utilizados para desidratação de lácteos. A definição do processo e suas condições está diretamente ligada aos custos de produção e à valorização do produto final. Devido ao estresse osmótico e térmico, muitas vezes durante a desidratação, faz-se necessária a incorporação de substâncias, como carreadores, termoprotetores, crioprotetores e estabilizantes, para melhorar o rendimento do processo, a preservação de nutrientes e até mesmo uma posterior reidratação do produto. Diante disto, esta revisão tem, como objetivo, apresentar as tecnologias disponíveis para a obtenção de iogurte em pó, descrevendo processos auxiliares de secagem, taxas e condições de sobrevivência das bactérias lácticas, além da reidratação.

Palavras-chave: Bactéria láctica; Conservação; Termoprotetores; Desidratação; Estabilidade; Reidratação.

\section{Introduction}

Yoghurt is the most popular fermented milk product in the world, and its consumption has increased due to consumer concern about healthier foods. Although yoghurt is an alternative for milk preservation, its shelf life is still short when compared to other dairy products, such as some types of cheese, and its nutritional value also makes the product suitable for the development of some spoilage microorganisms.
In this context, dehydration appears as a process for yoghurt preservation, and freeze drying and spray drying are the most recommended drying methods, mainly due to the maintenance of the sensory and nutritional characteristics of the foods (KOÇ et al., 2014; SAKIN-YILMAZER et al., 2014).

Freeze drying involves the sublimation of water from a frozen product under reduced pressure (vacuum) at a 
temperature usually below $-30^{\circ} \mathrm{C}$, resulting in a product with a moisture-free porous structure, capable of being reconstituted by the addition of water. Although the process maintains the sensory, biological and nutritional characteristics of the dried product close to those of the fresh product, the high operational costs are a major drawback of freeze drying, thus spray drying can be an alternative to freeze drying at a lower cost (MARQUES, 2008; VELARDI; BARRESI, 2008; FU; CHEN, 2011).

Spray drying enables the transformation of fluid products into dried particles by way of a centrifugal or high pressure system, where the atomized droplets come into immediate contact with the hot air flow, leading to instant water evaporation and preventing the thermal effects that compromise the sensory and biological characteristics of the products (MEZHERICHER et al., 2010).

Spray drying and freeze drying can be used to obtain yoghurt powder, contributing to a greater preservation of the yoghurt, and facilitating its transportation and storage without the need for a refrigerated environment. Freeze drying has the advantage of preserving the yoghurt microflora, since the process is carried out at low temperatures (KUMAR; MISHRA, 2004b; CAPELA et al., 2006).

Yoghurt powder could be used as an ingredient or supplement in juices, biscuits, ice cream, candies and milk beverages, besides replacing milk powder in recipes, hence adding nutritional and functional values to these products (KUMAR; MISHRA, 2004b; TAMIME; ROBINSON, 2007; ZUNGUR BASTIOĞLU et al., 2016).

Given the possible innovations in the development and applicability of new products, this study aims to carry out an upgrade of the drying technologies applied to yoghurt manufacture, including the quality parameters of the yoghurt powders and the effects of the drying processes on the lactic acid bacteria.

\section{Drying process}

In dairy manufacture, drying is usually associated with the maintenance of viable microorganisms, and various drying methods are used, such as fluidized bed, vacuum, convective drying, spouted bed and microwave processes. However, freeze drying and spray drying stand out as the most efficient methods, resulting in good-quality products (HAYALOGLU et al., 2007; OLIVEIRA et al., 2007). Table 1 shows the survival rate of the lactic acid bacteria in dried yoghurts.

\subsection{Freeze drying}

Freeze drying consists of a rapid freezing of the product, so that its nutritional and organoleptic characteristics are preserved. In the subsequent step, the frozen material is subjected to reduced pressure (vacuum) leading to sublimation of the frozen water, and the porous structure of the dried material facilitates rapid rehydration and retention of the flavour compounds. The freeze dried product can be consumed dry, rehydrated, or as ingredients in the formulation of other products (RATTI, 2001; BOSS et al., 2004; MATA et al., 2005).

Sharma and Arora (1995) have reported that factors such as particle size of the product and pressure of the drying chamber can affect the drying rates of yoghurt powder, with the best drying rates observed for a particle size with a thickness of $6.2 \mathrm{~mm}$ and pressure of $0.1 \mathrm{mmHg}$.

Table 1. Survival rate of lactic acid bacteria in yoghurts subjected to drying processes.

\begin{tabular}{|c|c|c|c|}
\hline Method & Microorganisms & After drying & Authors \\
\hline Spray drying & $\begin{array}{l}\text { L. bulgaricus and } \\
\text { S. thermophiles }\end{array}$ & $\sim 0.2 \%$ and $\sim 10 \%$ & Kearney et al. (2009) \\
\hline Spray drying & $\begin{array}{l}\text { L. bulgaricus and } \\
\text { S. thermophilus }\end{array}$ & $54.7 \%$ and $15.8 \%$ & Bielecka and Majkowska (2000) \\
\hline Spray drying & $\begin{array}{l}\text { L. bulgaricus and } \\
\text { S. thermophilus }\end{array}$ & reduction $10^{2} \mathrm{CFU} / \mathrm{g}$ & Koc et al. (2010) \\
\hline Spray drying & $\begin{array}{l}\text { L. bulgaricus and } \\
\text { S. thermophilus }\end{array}$ & reduction $\sim 3 \times 10^{2} \log \mathrm{CFU} / \mathrm{g}$ & Rascón-Díaz et al. (2012) \\
\hline Freeze drying & $\begin{array}{l}\text { L. bulgaricus and } \\
\text { S. thermophilus }\end{array}$ & $3 \times 10^{5} \mathrm{CFU} / \mathrm{g}$ and $7.6 \times 10^{8} \mathrm{CFU} / \mathrm{g}$ & Rybka et al. (1997) \\
\hline Freeze drying & $\begin{array}{l}\text { L. bulgaricus and } \\
\text { S. thermophilus }\end{array}$ & $2.1 \times 10^{7} \mathrm{CFU} / \mathrm{g}$ and $1.3 \times 10^{7} \mathrm{CFU} / \mathrm{g}$ & Bozoğlu et al. (1987) \\
\hline Freeze drying & $\begin{array}{l}\text { L. bulgaricus and } \\
\text { S. thermophilus }\end{array}$ & reduction $3 \times 10^{2} \log$ CFU/g and $89 \mathrm{CFU} / \mathrm{g}$ & Venir et al. (2007) \\
\hline Freeze drying & $\begin{array}{l}\text { L. bulgaricus and } \\
\text { S. thermophilus }\end{array}$ & reduction $4 \times 10^{3} \mathrm{CFU} / \mathrm{g}$ and $9 \times 10^{3} \mathrm{CFU} / \mathrm{g}$ & Kumar and Mishra (2004b) \\
\hline
\end{tabular}


Venir et al. (2007) evaluated the freeze drying of low-fat yoghurt and full-fat yoghurt containing sucrose $(10 \%)$ and blueberry (10\%). After freeze drying of the full fat yoghurt, reductions in the lactobacilli and streptococci counts of $1.7 \log \mathrm{CFU} / \mathrm{g}$ and $1.5 \mathrm{log} \mathrm{CFU} / \mathrm{g}$, respectively, were observed in the freezing stage, and of $2.5 \mathrm{log} \mathrm{CFU} / \mathrm{g}$ and $1.9 \mathrm{log}$ CFU/g during the drying stage, respectively. The samples containing sucrose and blueberry preserved the bacterial viability during the process, possibly due to a cryoprotective effect of the sucrose.

Sakin-Yilmazer et al. (2014a) investigated the freeze-drying of yoghurt containing nuts at concentrations of $5 \%, 10 \%$, and $20 \%$ by weight, and concluded that, regardless of the presence of the nuts, the yoghurt could be satisfactorily freeze dried. However, neither the samples with no addition of nuts nor those containing $5 \%$ nuts presented good rheological characteristics after reconstitution to the original moisture content, and only those formulated with $10 \%$ and $20 \%$ nuts maintained good characteristics.

Rybka and Kailasapathy (1997) found reductions of from $1.2 \times 10^{8} \mathrm{CFU} / \mathrm{g}$ to $3 \times 10^{5} \mathrm{CFU} / \mathrm{g}$ for L. delbrueckii subsp. Bulgaricus, and of $1.6 \times 10^{9} \mathrm{CFU} / \mathrm{g}$ to $7.6 \times 10^{8} \mathrm{CFU} / \mathrm{g}$ for $S$. thermophilus during the freeze drying of probiotic yoghurt, which demonstrates the greater sensitivity of the lactobacillus genus. Bozoğlu et al. (1987) studied the survival kinetics of lactic acid bacteria in yoghurt during freeze drying, and found reductions of from $1.61 \times 10^{8} \mathrm{CFU} / \mathrm{g}$ to $9.21 \times 10^{4} \mathrm{CFU} / \mathrm{g}$, and of $1.98 \times 10^{9} \mathrm{CFU} / \mathrm{g}$ to $1.30 \times 10^{7} \mathrm{CFU} / \mathrm{g}$ for L. delbrueckii subsp. bulgaricus, and $S$. thermophilus, respectively.

Damage to biological systems during freeze-drying can be due to changes in the physical state of the lipid membrane and in the protein structure (LESLIE et al., 1995). Wang et al. (2005) observed a greater cryotolerance for Lactobacillus delbrueckii subsp. bulgaricus at $-20{ }^{\circ} \mathrm{C}$, when the cells were cultured at $30^{\circ} \mathrm{C}$ to $37^{\circ} \mathrm{C}$ rather than at $42{ }^{\circ} \mathrm{C}$, while De Urraza and De Antoni (1997) reported that $\mathrm{L}$. bulgaricus cells pre-incubated at $30{ }^{\circ} \mathrm{C}$ for 60 minutes, with a fermentable sugar, became more resistant to freezing at $-20^{\circ} \mathrm{C}$, during 10 and 45 days of storage. The authors reported that this adaptation may be due to two combined physiological responses: a change in the membrane fatty acid composition affecting fluidity, and an increase in protein synthesis.

\subsection{Spray drying}

Spray drying is a technique commonly used in the food industry to improve product stability, in addition to obtaining specific properties, such as instant solubility (ROUSTAPOUR et al., 2009; PARAMITA et al., 2010). It is also considered the main technological drying process applied to dairy products due to low operational costs and high production rates (WIRJANTORO; PHIANMONGKHOL, 2009; KOÇ et al., 2014). Spray dried yoghurt powder has medium values for protein (36.09\%), lactose (44.78\%) and moisture $(5.08 \%)$, and a $\mathrm{pH}$ value of 5.39 (BIELECKA; MAJKOWSKA, 2000).

Many factors including the inlet and outlet temperatures, feed rate, nozzle pressure, material concentration and drying air velocity are involved in the viability of the cultures during spray drying, and inactivation is caused by the reduction in moisture content and exposure to high temperatures, causing damage to the DNA, RNA, proteins, lipids, membranes and ribosomes (FU; CHEN, 2011).

Wang et al. (2004) reported that the viability of the lactic acid bacteria decreased with increase in the outlet temperature of the spray drier. Fang et al. (2011) studied the effect of four spray drying temperatures $\left(77{ }^{\circ} \mathrm{C}, 107^{\circ} \mathrm{C}, 155^{\circ} \mathrm{C}\right.$ and $\left.178{ }^{\circ} \mathrm{C}\right)$ on the functionality of milk proteins, and found that the higher temperatures compromised the protein functionality and solubility, and that the caseins were more susceptible than the whey proteins (LAM; NICKERSON, 2015; GUERIN et al., 2017).

Rascón-Díaz et al. (2012) studied the effect of hydrocolloids on the spray drying of yoghurt, and confirmed that these compounds preserved the acetaldehyde levels at $92.6 \%$. Before spray drying, the Lactobacillus bulgaricus and Streptococcus thermophilus counts were $1.01 \times 10^{6} \mathrm{CFU} / \mathrm{g}$ and $2.51 \times 10^{8} \mathrm{CFU} / \mathrm{g}$, respectively, which changed to $2.7 \times 10^{6} \mathrm{CFU} / \mathrm{g}$ and $4.3 \times 10^{4} \mathrm{CFU} / \mathrm{g}$ after the process, and were still higher than the samples without hydrocolloids, thus demonstrating the protective effect of the gums. In addition, a significant improvement in the gel formed by the rehydrated product was observed.

A lower pressure of the evaporator nozzle during spray drying also contributed to survival of the lactic acid bacteria. Riveros et al. (2009) reported an increase in Lactobacillus acidophilus viability with a decrease in pressure from $100 \mathrm{kPa}$ to $50 \mathrm{kPa}$, with counts of 8.62 and $9.48 \mathrm{log} C F U / g$ at $100 \mathrm{kPa}$ and $50 \mathrm{kPa}$, respectively. Lievense and Van't Riet (1994) reported an increase of $0.8 \%$ and $1.5 \%$ in survival of Lactobacillus bulgaricus, when the spray pressure was reduced from $200 \mathrm{kPa}$ to $100 \mathrm{kPa}$.

Several studies have been carried out on the maintenance of lactic acid bacteria at acceptable levels during the spray drying of dairy products, especially of yoghurt.

Kearney et al. (2009) assessed the viability of Lactobacillus paracasei NFBC 338 in yoghurt subjected to spray drying with an inlet temperature of $170^{\circ} \mathrm{C} \pm 2^{\circ} \mathrm{C}$ and outlet temperature of $80^{\circ} \mathrm{C}$ to $85^{\circ} \mathrm{C}$, and found probiotic counts of $3.4 \times 10^{8}, 1.2 \times 10^{8}$ and $4.0 \times 10^{5} \mathrm{CFU} / \mathrm{g}$ for the probiotic bacterium, Streptococcus thermophilus and Lactobacillus bulgaricus, respectively, after drying. After 42 days of storage of the yoghurt powder at $4{ }^{\circ} \mathrm{C}$ and $15^{\circ} \mathrm{C}$, the Lactobacillus paracasei NFBC 338 and Streptococcus thermophilus counts remained above $10^{7} \mathrm{CFU} / \mathrm{g}$. Wirjantoro and 
Phianmongkhol (2009) investigated the survival of the probiotic cultures $L$. acidophilus and B. bifidum in yoghurt powder obtained by spray drying. The authors used an air inlet temperature of $180^{\circ} \mathrm{C} \pm 2{ }^{\circ} \mathrm{C}$ and outlet temperature of $80^{\circ} \mathrm{C} \pm 2^{\circ} \mathrm{C}$ in their experiments. After drying, the survival rates were $47.43 \%$ and $47.75 \%$ for L. acidophilus and B. bifidum, respectively. After four weeks of storage, the L. acidophilus survival rate remained at $70 \%$, which was not observed for $B$. bifidum. The authors concluded that yoghurt powder could be an alternative for the delivery of probiotic microorganisms.

Koc et al. (2010) assessed the best spray drying conditions to obtain yoghurt powder by varying the air inlet temperature $\left(150^{\circ} \mathrm{C}\right.$ to $\left.180^{\circ} \mathrm{C}\right)$, and obtained better powders in terms of cell viability and less physicochemical change during storage with an air inlet temperature of $171^{\circ} \mathrm{C}$, outlet temperature of $60.5^{\circ} \mathrm{C}$ and feed temperature of $15^{\circ} \mathrm{C}$. Bielecka and Majkowska (2000) varied the air outlet temperature $\left(60^{\circ} \mathrm{C}\right.$ to $\left.80^{\circ} \mathrm{C}\right)$, and found that this temperature affected bacterial viability, and the highest survival rate was observed with outlet temperatures between $60^{\circ} \mathrm{C}$ and $65^{\circ} \mathrm{C}$. However, this temperature range resulted in powders with high moisture contents (10.2\%), affecting the texture of the final product. Spray dried powders produced at an outlet temperature of $80^{\circ} \mathrm{C}$ presented significantly lower bacterial counts and lower moisture contents (4.4\%). Thus, the optimal temperature range for satisfactory survival rates was $70^{\circ} \mathrm{C}$ to $75^{\circ} \mathrm{C}$ ( L. delbrueckii subsp bulgaricus $13.7 \%$ to $15.8 \%$; S. thermophilus $51.6 \%$ to $54.7 \%$ ), and moisture contents from $5.1 \%$ to $6.3 \%$.

To attenuate the effect of exposure to high temperatures during drying on the lactic acid bacteria, some authors have suggested the use of combined drying methods such as spray drying - vacuum drying, or spray drying - fluidized bed drying. The product is first subjected to spray drying, during which most of the water is eliminated and small particles are formed, and drying then completed using a fluidized bed system at a mild temperature, causing agglomeration of the particles, which facilitates rehydration, thus obtaining a higher quality product (KUMAR; MISHRA, 2004a).

\subsection{Auxiliary drying}

Protective agents can be used during microbial growth, before freezing and drying. Although the type of protection is largely dependent on the microorganism, there are some protectors that seem to work well with many species (HUBÁLEK, 2003).

The auxiliary drying agents include carbohydrates (maltodextrin, dextrin, starch, cellulose, sucrose, trehalose, maltose), hydrocolloids (xanthan, guar and acacia), proteins (gluten, casein, gelatine and albumin), polyhydric alcohols (sorbitol, mannitol), associated with anti-wetting agents (phosphates, silicates, silicon dioxide and calcium salts) used for moisture absorption. These compounds assist in the drying process, increasing the drying rate or preserving the sensory and microbiological characteristics of the food (SANTIVARANGKNA et al., 2008; JAYA; DAS, 2009; SUNNY-ROBERTS; KNORR, 2009; BARBOSA, 2010; JULIANO; BARBOSA-CÁNOVAS, 2010; MESTRY et al., 2011).

Furthermore, these agents can react with cellular structures and stabilize the microbial cells during drying and rehydration, besides acting as a physical barrier alleviating thermal and osmotic stress (FU; CHEN, 2011). According to Chávez and Ledeboer (2007), sugars, in particular disaccharides, may replace water molecules and preserve membrane structures during the osmotic stress caused by dehydration. Their accumulation within the cell balances the osmotic difference between the inside and outside of the cell membrane, and also slowing protein denaturation. Thus a combination of different protective agents may be used to enhance bacterial survival during spray drying (DESMOND et al., 2001).

Auxiliary drying also contributes to the retention of aromatic compounds during processing and storage. It has been reported that most of the aroma compounds and rheological characteristics are lost during spray drying. It is known that complex morphological changes (size, shape and appearance) may occur during the process and that the retention and protection of volatile compounds are related to the porosity and integrity of the microcapsules (PEREZ et al., 1997). The addition of hydrocolloids (carrageenan, xanthan, gellan) improves the retention of the volatiles as well as the solubility and dispersibility of the spray dried yoghurt during rehydration (RAMIREZ et al., 2002).

Kumar and Mishra (2005) reported that the addition of stabilizers such as pectin, gelatine and sodium alginate reduced the drying time by $15 \%$ due to an increase in the effective moisture diffusivity, and also increased powder dispersibility. The addition of gelatine provided higher bacterial survival rates during drying, with mean lactic acid bacterial counts of $\left(3.8 \times 10^{7} \mathrm{CFU} / \mathrm{g}\right)$, whilst the control sample showed a count of $\left(3.4 \times 10^{7} \mathrm{CFU} / \mathrm{g}\right)$. There was also a greater retention of acetaldehyde but colour degradation was observed in the samples containing stabilizers.

Lian et al. (2002) investigated the survival rate of Bifidobacterium cultures subjected to spray drying, and found that the use of $10 \%$ (w/w) gelatine, gum Arabic or soluble starch led to higher survival rates. Ananta et al. (2005) used 20\% (w/w) reconstituted skim milk powder (RSMP) in the spray drying of Lactobacillus rhamnosus GG and proved that the RSMP led to a microbial survival rate of $60 \%$ at an air outlet temperature of $80^{\circ} \mathrm{C}$. These compounds form microcapsules which assist in preserving the bacteria during drying. 


\section{Packaging and stability of dehydrated yoghurts}

During storage of the yoghurt powder, the oxygen content, temperature, $\mathrm{pH}$, water activity and high solute concentrations can affect the viability of the microorganisms (CARVALHO et al., 2004). Various studies have shown that temperature is an important parameter for bacterial survival during storage. As expected, the stability of the spray dried samples decreased during storage, and low storage temperatures can contribute to higher survival rates (DESMOND et al., 2001; SILVA et al., 2002; BOZA et al., 2004; CORCORAN et al., 2004).

Rybka and Kailasapathy (1995) studied the effect of freeze drying on probiotic yoghurt, and concluded that the probiotic microorganisms in the freeze dried yoghurt were viable for 2 months of storage at room temperature, with values of $3 \times 10^{8} \mathrm{CFU} / \mathrm{g}$ for $S$. thermophillus and $4 \times 10^{5} \mathrm{CFU} / \mathrm{g}$ for L. delbrueckii subsp. bulgaricus. Capela et al. (2006) found that although viable numbers of microorganisms were observed in the freeze dried yoghurt for up to 1 month of storage at $37^{\circ} \mathrm{C}$, the bacterial cells remained viable for 6 months when the yoghurt was stored at $4{ }^{\circ} \mathrm{C}$.

Proper packaging is another important factor for maintaining bacterial viability after drying processes. Packaging under vacuum or nitrogen replacement is suitable for storing anaerobic probiotics such as Bifidobacteria (CHÁVEZ; LEDEBOER, 2007).

Kumar and Mishra (2004a) investigated vacuum sealed yoghurt stored at $38{ }^{\circ} \mathrm{C}$ and $90 \% \mathrm{RH}$. The shelf life was estimated at 45 and 54 days for high density polypropylene (HDPP) and aluminium laminated polyethylene (ALP) packaging, respectively. The authors used the parameter of moisture to calculate the product shelf life, and concluded that moisture levels from $6.8 \%$ to $7.2 \%$ were decisive for product quality, since higher values led to particle agglomeration. In addition, it is worth mentioning that darkening is common under inadequate storage conditions, with the development of off-tastes due to the formation of insoluble compounds from the Maillard reaction (ZARE et al., 2011).

Wang et al. (2004) analysed soy yoghurt powder stored in glass, polyethylene terephthalate (PET) and laminated packages at $4{ }^{\circ} \mathrm{C}$. The results showed that the laminated packaging preserved the product best after 4 months of storage, with $57.7 \%$ and $29.5 \%$ bacterial survival in the freeze dried and spray dried samples, respectively.

The water content is another important parameter for the stability of yoghurt powder, and can be affected by the type of packaging, composition of the medium, storage atmosphere and bacterial species (WANG et al., 2004; SANTIVARANGKNA et al., 2008). To allow for long-term storage, dehydrated foods must have a water activity and moisture content of $\sim 0.3$ and $\sim 5 \%$, respectively (CHÁVEZ; LEDEBOER, 2007).

Kearney et al. (2009) found water activity values of from 0.21 to 032 in probiotic yoghurt powders. According to Passot et al. (2012), the optimal water activity and moisture levels may vary from 0.1 to 0.24 and from $2.5 \%$ to $3.7 \%$, respectively, for $L b$. bulgaricus CFL1 freeze dried in a sucrose matrix.

\section{Rehydration}

Four properties are fundamental for a successful reconstitution of dairy powder products, including wettability, immersibility, dispersibility and solubility. The wettability of particles is essential to control the hydration rate, and various studies have focused on this subject. It was found that rapid drying provided an increase in the number of pores, reducing the contact angle between the surface of the powder and the rehydration medium, thus facilitating rehydration. Agglomeration and the addition of emulsifiers can also contribute to processing efficiency, especially when the powder is rich in lipids and the rehydration medium is hydrophilic (FREUDIG et al., 1999; KIM et al., 2002).

Rehydration is also a key point to ensure the viability of lactic acid bacteria in fermented powders. Several factors, including the solution used for rehydration, time, temperature and hydration rate are decisive for an increase in bacterial survival rates (MASTERS; HANDBOOK, 1990; SILVA; MEDEIROS, 2003).

Various media can be used for rehydration, such as skim milk, sucrose solution, phosphate buffer, sodium glutamate and water (COSTA et al., 2000). Abadias et al. (2001) suggested that the medium used before drying should also be used for rehydration, softening the osmotic shock and increasing cell regeneration.

The temperature of the rehydration medium may also affect cell recovery after drying. An increase in temperature between $4^{\circ} \mathrm{C}$ and $50^{\circ} \mathrm{C}$ linearly increased the viability of L. bulgaricus (TEIXEIRA et al., 1995). Similar results were found by (WANG et al., 2004) with S. thermophilus and $B$. longum subjected to spray drying.

The rehydration time is also an important factor, since studies have shown that rapid (2 minutes) or slow (30 min) rehydration can affect the viability of $L$. bulgaricus. Slow rehydration (immersion) led to higher cell viability, possibly because the immersion method restricts osmotic shock (TEIXEIRA et al., 1995).

Rybka and Kailasapathy (1997) and Venir et al. (2007) found a loss of consistency of the reconstituted freeze-dried yoghurt, indicating an irreversible weakening of the gel network structure, probably due to the mechanical energy required to incorporate water for rehydration. Venir et al. (2007) investigated water reduction in the rehydration process as a way of compensating the lower 
Powdered yoghurt produced by spray drying and freeze drying: a review

Santos, G. et al.

mechanical strength. The samples had 100\%, 70\%, and $60 \%$ of the initial water content, which corresponded to $11 \%, 15 \%$ and $17 \%$ solids, respectively. The results showed that the product rehydrated with $70 \%$ of the initial water had the best rheological characteristics. However, considering a possible marketing of the product, the water content depends on consumer acceptance.

As reported by Sakin-Yilmazer et al. (2014b), the dried yoghurt after reconstitution requires rheological behaviour comparable to yhat of fresh yoghurt, since the rheological and structural properties are closely related to the sensory quality criteria, such as softness and firmness in the mouth and on the spoon, which directly affect consumer acceptance. The authors rehydrated yoghurt powder to obtain different solids contents in the final product, and concluded that the product with $30 \%$ solids had rheological characteristics closer to those of the traditional product containing $14 \%$ solids.

\section{Conclusion}

Freeze drying and spray drying can be used to obtain yoghurt powder with appreciable nutritional and sensory characteristics. Previous studies on yoghurt drying focused on the preservation of lactic acid bacteria, and Lactobacillus bulgaricus was more susceptible to the osmotic stress caused by dehydration than Streptococcus thermophilus. Although freeze drying preserves the microbiological and sensory characteristics of yoghurt when compared to spray drying, promising results have been found for spray drying. Some aspects such as drying kinetics, rehydration, and changes during storage (temperature, atmospheric conditions, sensory loss, and bacterial viability) need to be further studied to obtain the most suitable conditions for the production and marketing of yoghurt powder.

\section{References}

ABADIAS, M.; TEIXIDÓ, N.; USALL, J.; BENABARRE, A.; VIÑAS, I. Viability, efficacy, and storage stability of freeze-dried biocontrol agent Candida sake using different protective and rehydration media. Journal of Food Protection, v. 64, n. 6, p. 856-861, 2001. http://dx.doi.org/10.4315/0362-028X-64.6.856. PMid:11403138.

ANANTA, E.; VOLKERT, M.; KNORR, D. Cellular injuries and storage stability of spray-dried Lactobacillus rhamnosus GG. International Dairy Journal, v. 15, n. 4, p. 399-409, 2005. http:// dx.doi.org/10.1016/j.idairyj.2004.08.004.

BARBOSA, S. J. Qualidade de suco em pó de mistura de frutas obtido por spray drying. 2010. 107 f. Dissertação (Mestrado, Programa de Pós-Graduação em Produção Vegetal no Semiárido)Universidade Estadual de Montes Claros-Unimontes, Montes Claros -MG, 2010.
BIELECKA, M.; MAJKOWSKA, A. Effect of spray drying temperature of yoghurt on the survival of starter cultures, moisture content and sensoric properties of yoghurt powder. Food/Nahrung, v. 44, n. 4, p. 257-260, 2000. http://dx.doi.org/10.1002/15213803(20000701)44:4<257::AID-FOOD257>3.0.CO;2-E. PMid:10996900.

BOSS, E. A.; MACIEL FILHO, R.; DE TOLEDO, E. C. V. Freeze drying process: real time model and optimization. Chemical Engineering and Processing: Process Intensification, $V$. 43, n. 12, p. 1475-1485, 2004. http://dx.doi.org/10.1016/j. cep.2004.01.005.

BOZA, Y.; BARBIN, D.; SCAMPARINI, A. Effect of spray-drying on the quality of encapsulated cells of Beijerinckia sp. Process Biochemistry, v. 39, n. 10, p. 1275-1284, 2004. http://dx.doi. org/10.1016/j.procbio.2003.06.002.

BOZOǦLU, T.; ÖZILGEN, M.; BAKIR, U. Survival kinetics of lactic acid starter cultures during and after freeze drying. Enzyme and Microbial Technology, v. 9, n. 9, p. 531-537, 1987. http:// dx.doi.org/10.1016/0141-0229(87)90082-2.

CAPELA, P.; HAY, T.; SHAH, N. Effect of cryoprotectants, prebiotics and microencapsulation on survival of probiotic organisms in yoghurt and freeze-dried yoghurt. Food Research International, v. 39, n. 2, p. 203-211, 2006. http://dx.doi.org/10.1016/j. foodres.2005.07.007.

CARVALHO, A. S.; SILVA, J.; HO, P.; TEIXEIRA, P.; MALCATA, F. $X$; GIBBS, P. Relevant factors for the preparation of freeze-dried lactic acid bacteria. International Dairy Journal, v. 14, n. 10, p. 835-847, 2004. http://dx.doi.org/10.1016/j.idairyj.2004.02.001.

CHÁVEZ, B.; LEDEBOER, A. Drying of probiotics: optimization of formulation and process to enhance storage survival. Drying Technology, v. 25, n. 7-8, p. 1193-1201, 2007. http://dx.doi. org/10.1080/07373930701438576.

CORCORAN, B. M.; ROSS, R. P.; FITZGERALD, G. F.; STANTON, C. Comparative survival of probiotic lactobacilli spray dried in the presence of prebiotic substances. Journal of Applied Microbiology, v. 96, n. 5, p. 1024-1039, 2004. http://dx.doi. org/10.1111/j.1365-2672.2004.02219.x. PMid:15078519.

COSTA, E.; USALL, J.; TEIXIDÓ, N.; GARCIA, N.; VIÑAS, I. Effect of protective agents, rehydration media and initial cell concentration on viability of Pantoea agglomerans strain CPA 2 subjected to freeze drying. Journal of Applied Microbiology, v. 89, n. 5, p. 793-800, 2000. http://dx.doi.org/10.1046/j.13652672.2000.01182.x. PMid:11119153.

DE URRAZA, P.; DE ANTONI, G. Induced cryotolerance of lactobacillus delbrueckii subsp. bulgaricus lbb by preincubation at suboptimal temperatures with a fermentable sugar. Cryobiology, v. 35, n. 2, p. 159-164, 1997. http://dx.doi.org/10.1006/cryo.1997.2036.

DESMOND, C.; STANTON, C.; FITZGERALD, G. F.; COLLINS, K.; PAUL ROSS, R. P Environmental adaptation of probiotic lactobacilli towards improvement of performance during spray 
Powdered yoghurt produced by spray drying and freeze drying: a review

Santos, G. et al.

drying. International Dairy Journal, v. 11, n. 10, p. 801-808, 2001. http://dx.doi.org/10.1016/S0958-6946(01)00121-2.

FANG, Y.; ROGERS, S.; SELOMULYA, C.; CHEN, X. D. Functionality of milk protein concentrate: effect of spray drying temperature. Biochemical Engineering Journal, v. 62, p. 101-105, 2011. http://dx.doi.org/10.1016/j.bej.2011.05.007

FREUDIG, B.; HOGEKAMP, S.; SCHUBERT, H. Dispersion of powders in liquids in a stirred vessel. Chemical Engineering and Processing: Process Intensification, v. 38, n. 4, p. 525-532, 1999. http://dx.doi.org/10.1016/S0255-2701(99)00049-5.

FU, N.; CHEN, X. D. Towards a maximal cell survival in convective thermal drying processes. Food Research International, v. 44, n. 5, p. 1127-1149, 2011. http://dx.doi.org/10.1016/j. foodres.2011.03.053.

GUERIN, J.; PETIT, J.; BURGAIN, J.; BORGES, F.; BHANDARI, B.; PERROUD, C.; DESOBRY, S.; SCHER, J.; GAIANI, C. Lactobacillus rhamnosus $G G$ encapsulation by spray-drying: milk proteins clotting control to produce innovative matrices. Journal of Food Engineering, v. 193, p. 10-19, 2017. http://dx.doi.org/10.1016/j. jfoodeng.2016.08.008.

HAYALOGLU, A. A.; KARABULUT, I.; ALPASLAN, M.; KELBALIYEV, $G$. Mathematical modeling of drying characteristics of strained yoghurt in a convective type tray-dryer. Journal of Food Engineering, v. 78, n. 1, p. 109-117, 2007. http://dx.doi. org/10.1016/j.jfoodeng.2005.09.006.

HUBÁLEK, Z. Protectants used in the cryopreservation of microorganisms. Cryobiology, v. 46, n. 3, p. 205-229, 2003. http:// dx.doi.org/10.1016/S0011-2240(03)00046-4. PMid:12818211.

JAYA, S.; DAS, H. Glass transition and sticky point temperatures and stability/mobility diagram of fruit powders. Food and Bioprocess Technology, v. 2, n. 1, p. 89-95, 2009. http://dx. doi. org/10.1007/s11947-007-0047-5.

JULIANO, P.; BARBOSA-CÁNOVAS, G. V. Food powders flowability characterization: theory, methods, and applications. Annual Review of Food Science and Technology, v. 1, n. 1, p. 211-239, 2010. http://dx.doi.org/10.1146/annurev.food.102308.124155. PMid:22129336

KEARNEY, N.; MENG, X. C.; STANTON, C.; KELLY, J.; FITZGERALD, G. F.; ROSS, R. P. Development of a spray dried probiotic yoghurt containing Lactobacillus paracasei NFBC 338. International Dairy Journal, v. 19, n. 11, p. 684-689, 2009. http://dx.doi. org/10.1016/j.idairyj.2009.05.003.

KIM, E. H. J.; CHEN, X. D.; PEARCE, D. Surface characterization of four industrial spray-dried dairy powders in relation to chemical composition, structure and wetting property. Colloids and Surfaces. B, Biointerfaces, v. 26, n. 3, p. 197-212, 2002. http:// dx.doi.org/10.1016/S0927-7765(01)00334-4.

KOÇ, B.; SAKIN-YILMAZER, M.; KAYMAK-ERTEKIN, F.; BALKIR, P. Physical properties of yoghurt powder produced by spray drying. Journal of Food Science and Technology, v. 51, n.
7, p. 1377-1383, 2014. http://dx.doi.org/10.1007/s13197-0120653-8. PMid:24966433.

KOC, B.; YILMAZER, M. S.; BALKIR, P.; ERTEKIN, F. K. Spray drying of yoghurt: optimization of process conditions for improving viability and other quality attributes. Drying Technology, v. 28, n. 4, p. 495-507, 2010. http://dx.doi.org/10.1080/07373931003613809.

KUMAR, P.; MISHRA, H. Effect of stabilizer on drying characteristics and quality of mango soy fortified yoghurt. European Food Research and Technology, v. 220, n. 5-6, p. 483-488, 2005. http://dx.doi.org/10.1007/s00217-004-1085-0.

KUMAR, P.; MISHRA, H. Storage stability of mango soy fortified yoghurt powder in two different packaging materials: HDPP and ALP. Journal of Food Engineering, v. 65, n. 4, p. 569-576, 2004 a. http://dx.doi.org/10.1016/j.jfoodeng.2004.02.022.

KUMAR, P.; MISHRA, H. N. Yoghurt powder: review of process technology, storage and utilization. Food and Bioproducts Processing, v. 82, n. 2, p. 133-142, 2004b. http://dx.doi. org/10.1205/0960308041614918.

LAM, R. S.; NICKERSON, M. T. The effect of $\mathrm{pH}$ and temperature pre-treatments on the physicochemical and emulsifying properties of whey protein isolate. Lebensmittel-Wissenschaft + Technologie, v. 60, n. 1, p. 427-434, 2015. http://dx.doi. org/10.1016/j.lwt.2014.07.031.

LESLIE, S. B.; ISRAELI, E.; LIGHTHART, B.; CROWE, J. H.; CROWE, L. M. Trehalose and sucrose protect both membranes and proteins in intact bacteria during drying. Applied and Environmental Microbiology, v. 61, n. 10, p. 3592-3597, 1995. PMid:7486995.

LIAN, W. C.; HSIAO, H. C.; CHOU, C. C. Survival of bifidobacteria after spray-drying. International Journal of Food Microbiology, v. 74, n. 1-2, p. 79-86, 2002. http://dx.doi.org/10.1016/S01681605(01)00733-4. PMid:11929173.

LIEVENSE, L. C.; VAN'T RIET, K. Convective drying of bacteria. In: SCHEPER, T; BELKIN, S.; BLEY, T., BOHLMANN, J.; GU, M. B.; HU, W.-S.; MATTIASSON, B.; NIELSEN, J.; SEITZ, H.; ULBER, R.; ZENG, A.-P.; ZHONG, J.-J.; ZHOU, W. (Ed.). Advances in biochemical engineering/biotechnology. Berlin: Springer, 1994. p. 71-89. (Biotechnics/Wastewater, 51). http://dx.doi. org/10.1007/BFb0008734.

MARQUES L. G. Liofilização de frutas tropicais. 2008. 293 f. Tese (Doutorado em Ciências Exatas e da Terra)-Universidade Federal de São Carlos, São Carlos, 2008.

MASTERS, K.; HANDBOOK, S. D. Spray drying handbook. Wisconsin-Madison, Longman Scientific and Technical, 1990.

MATA, M. E. R. M. C.; DUARTE, M. E. M.; ALSEMO, G. C. S.; RODRIGUES, E.; GUEDES, M. A.; CAVALCANTI, A. S. R. R. M.; OLIVEIRA, C. C. A. Obtenção de graviola em pó pelo processo de liofilização. Revista Brasileira de Produtos Agroindustriais, v. 7, n. 2, p. 165-172, 2005. http://dx.doi.org/10.15871/15178595/rbpa.v7n2p165-172. 
Powdered yoghurt produced by spray drying and freeze drying: a review

Santos, G. et al.

MESTRY, A.; MUJUMDAR, A.; THORAT, B. Optimization of spray drying of an innovative functional food: fermented mixed juice of carrot and watermelon. Drying Technology, v. 29, n. 10, p. 11211131, 2011. http://dx.doi.org/10.1080/07373937.2011.566968.

MEZHERICHER, M.; LEVY, A.; BORDE, I. Spray drying modelling based on advanced droplet drying kinetics. Chemical Engineering and Processing: Process Intensification, v. 49, n. 11, p. 12051213, 2010. http://dx.doi.org/10.1016/j.cep.2010.09.002.

PARAMITA, V.; IIDA, K.; YOSHII, H.; FURUTA, T. Effect of additives on the morphology of spray-dried powder. Drying Technology, v. 28, n. 3, p. 323-329, 2010. http://dx.doi. org/10.1080/07373931003627098.

PASSOT, S.; CENARD, S.; DOUANIA, I.; TRÉLÉA, I. C.; FONSECA, F. Critical water activity and amorphous state for optimal preservation of lyophilised lactic acid bacteria. Food Chemistry, v. 132, n. 4, p. 1699-1705, 2012. http://dx.doi.org/10.1016/j. foodchem.2011.06.012.

PEREZ, S. A.; SALGADO, C. M.; GARCIA, G. H. Acetaldehyde retention during spray drying of yoghurt. Milchwissenschaft. Milk Science International, v. 52, n. 2, p. 89-93, 1997

RAMIREZ, F. E.; SALGADO, C. M. A.; RODRIGUEZ, G. C.; GARCIA, H. S. Addition of hydrocolloids to improve the functionality of spray dried yoghurt. Milchwissenschaft. Milk Science International, v. 57, n. 2, p. 87-89, 2002

RASCÓN-DÍAZ, M. P.; TEJERO, J. M.; MENDOZA-GARCIA, P. G.; GARCÍA, H. S.; SALGADO-CERVANTES, M. A. Spray drying yoghurt incorporating hydrocolloids: structural analysis, acetaldehyde content, viable bacteria, and rheological properties. Food and Bioprocess Technology, v. 5, n. 2, p. 560-567, 2012. http:// dx.doi.org/10.1007/s11947-009-0312-x.

RATTI, C. Hot air and freeze-drying of high-value foods: a review. Journal of Food Engineering, v. 49, n. 4, p. 311-319, 2001. http://dx.doi.org/10.1016/S0260-8774(00)00228-4.

RIVEROS, B.; FERRER, J.; BORQUEZ, R. Spray drying of a vaginal probiotic strain of Lactobacillus acidophilus. Drying Technology, v. 27, n. 1, p. 123-132, 2009. http://dx.doi. org/10.1080/07373930802566002.

ROUSTAPOUR, O. R.; HOSSEINALIPOUR, M.; GHOBADIAN, B.; MOHAGHEGH, F.; AZAD, N. M. A proposed numerical -experimental method for drying kinetics in a spray dryer. Journal of Food Engineering, v. 90, n. 1, p. 20-26, 2009. http://dx.doi. org/10.1016/j.jfoodeng.2008.05.031.

RYBKA, S.; KAILASAPATHY, K. The survival of culture bacteria in fresh and freeze-dried $A B$ yoghurts. Australian Journal of Dairy Technology, v. 50, n. 2, p. 51-57, 1995.

RYBKA, S.; KAILASAPATHY, K. Effect of freeze drying and storage on the microbiological and physical properties of AB-yoghurt. Milchwissenschaft. Milk Science International, v. 52, n. 7, p. 390-394, 1997
SAKIN-YILMAZER, M.; DIRIM, S. N.; DI PINTO, D.; KAYMAKERTEKIN, F. Yoghurt with candied chestnut: freeze drying, physical, and rheological behaviour. Journal of Food Science and Technology, v. 51, n. 12, p. 3949-3955, 2014a. http://dx.doi. org/10.1007/s13197-012-0890-x. PMid:25477665.

SAKIN-YILMAZER, M.; KOÇ, B.; BALKIR, P.; KAYMAK-ERTEKIN, F. Rheological behavior of reconstituted yoghurt powder - an optimization study. Powder Technology, v. 266, p. 433-439, 2014b. http://dx.doi.org/10.1016/j.powtec.2014.06.060.

SANTIVARANGKNA, C.; KULOZIK, U.; FOERST, P. Inactivation mechanisms of lactic acid starter cultures preserved by drying processes. Journal of Applied Microbiology, v. 105, n. 1, p. 1-13, 2008. http://dx.doi.org/10.1111/j.1365-2672.2008.03744.x. PMid:18266696.

SHARMA, N. K.; ARORA, C. P. Influence of product thickness, chamber pressure and heating conditions on production rate of freeze-dried yoghurt. International Journal of Refrigeration, v. 18, n. 5, p. 297-307, 1995. http://dx.doi.org/10.1016/01407007(95)00025-7

SILVA, J.; CARVALHO, A. S.; TEIXEIRA, P.; GIBBS, P. A. Bacteriocin production by spray dried lactic acid bacteria. Letters in Applied Microbiology, v. 34, n. 2, p. 77-81, 2002. http://dx. doi. org/10.1046/j.1472-765x.2002.01055.x. PMid:11849498.

SILVA, L. S. C.; MEDEIROS, M. L. Processamento de achocolatado de cupuaçu por spray-dryer. Brazilian Journal of Pharmaceutical Sciences, v. 39, n. 1, p. 116-122, 2003.

SUNNY-ROBERTS, E.; KNORR, D. The protective effect of monosodium glutamate on survival of Lactobacillus rhamnosus GG and Lactobacillus rhamnosus E-97800 (E800) strains during spray-drying and storage in trehalose-containing powders. International Dairy Journal, v. 19, n. 4, p. 209-214, 2009. http:// dx.doi.org/10.1016/j.idairyj.2008.10.008.

TAMIME, A.; ROBINSON, R. Traditional and recent developments in yoghurt production and related products. In: TAMIME, A. Y.; ROBINSON, R. K. (Ed.). Tamime and Robinson's yoghurt: science and technology. Cambridge: Woohead Publishing Limited, 2007. cap. 5, p. 348-467

TEIXEIRA, P.; CASTRO, H.; KIRBY, R. Spray drying as a method for preparing concentrated cultures of Lactobacillus bulgaricus. The Journal of Applied Bacteriology, v. 78, n. 4, p. 456-462, 1995. http://dx.doi.org/10.1111/j.1365-2672.1995.tb03433.x.

VELARDI, S. A.; BARRESI, A. A. Development of simplified models for the freeze-drying process and investigation of the optimal operating conditions. Chemical Engineering Research \& Design, v. 86, n. 1, p. 9-22, 2008. http://dx.doi.org/10.1016/j. cherd.2007.10.007.

VENIR, E.; DEL TORRE, M.; STECCHINI, M. L.; MALTINI, E.; DI NARDO, P. Preparation of freeze-dried yoghurt as a space food. Journal of Food Engineering, v. 80, n. 2, p. 402-407, 2007. http://dx.doi.org/10.1016/j.jfoodeng.2006.02.030. 
Powdered yoghurt produced by spray drying and freeze drying: a review

Santos, G. et al.

WANG, Y. C.; YU, R. C.; CHOU, C. C. Viability of lactic acid bacteria and bifidobacteria in fermented soymilk after drying, subsequent rehydration and storage. International Journal of Food Microbiology, v. 93, n. 2, p. 209-217, 2004. http://dx. doi. org/10.1016/j.ijfoodmicro.2003.12.001. PMid:15135959.

WANG, Y.; CORRIEU, G.; BÉAL, C. Fermentation pH and temperature influence the cryotolerance of Lactobacillus acidophilus RD758. Journal of Dairy Science, v. 88, n. 1, p. 21-29, 2005. http:// dx.doi.org/10.3168/jds.S0022-0302(05)72658-8. PMid:15591363.

WIRJANTORO, T. I.; PHIANMONGKHOL, A. The viability of lactic acid bacteria and Bifidobacterium bifidum in yoghurt powder during storage. Journal of Natural Sciences, v. 8, n. 1, p. 95-104, 2009.

ZARE, F.; BOYE, J.; ORSAT, V.; CHAMPAGNE, C.; SIMPSON, B. Microbial, physical and sensory properties of yogurt supplemented with lentil flour. Food Research International, v. 44, n. 8, p. 2482-2488, 2011. http://dx.doi.org/10.1016/j.foodres.2011.01.002. ZUNGUR BASTIOĞLU, A.; DIRIM, S. N.; KAYMAK ERTEKIN, F. Moisture sorption isotherms of yogurt powder containing candied chestnut puree. Turkish Journal of Agriculture-Food Science and Technology, v. 4, n. 8, p. 676-683, 2016. http:// dx.doi.org/10.24925/turjaf.v4i8.676-683.681. 